\title{
Connessioni (im)materiali per una rigenerazione sostenibile
}

\author{
Saverio D'Auria \\ Lia Maria Papa
}

Abstract

Il contributo affronta alcuni aspetti di non poco conto per il settore del Disegno, relativi a un tema ampio come quello della valorizzazione di alcuni territori a matrice rurale, nei quali la già presente crisi identitaria è stata esasperata dalla situazione pandemica attuale che sta incidendo soprattutto sulle fasce più deboli della popolazione, non sostenute da adeguate risorse economiche e competenze digitali, e avvezze a perpetuare, attraverso rapporti interpersonali, modi di vivere e culture locali. II caso studio presentato, relativo a un comune della penisola sorrentina, si colloca nell'ambito di una ricerca più ampia che mira a definire un processo multiscalare di conoscenza e partecipazione che si dispiega nel dominio digitale.

In tale contesto, lo studio dei percorsi, intesi come alvei di connessioni fisiche e contenitori di flussi, diventa un fondamentale tassello per riscoprire le peculiarità identitarie degli originari insediamenti, evidenziando l'esigenza di mettere a sistema un processo conoscitivo teso a orientare coerenti e prioritarie iniziative progettuali di fruizione ampliata, materiali e immateriali, con l'ausilio di strumenti digitali, hardware e software, utili anche a svolgere un'azione educativa tra le giovani generazioni, per favorire la comprensione dei luoghi e riscoprire la loro memoria.

\section{Parole chiave}

identità, connessioni, ambienti digitali, rilievo 3D, fruizione multigenerazionale.

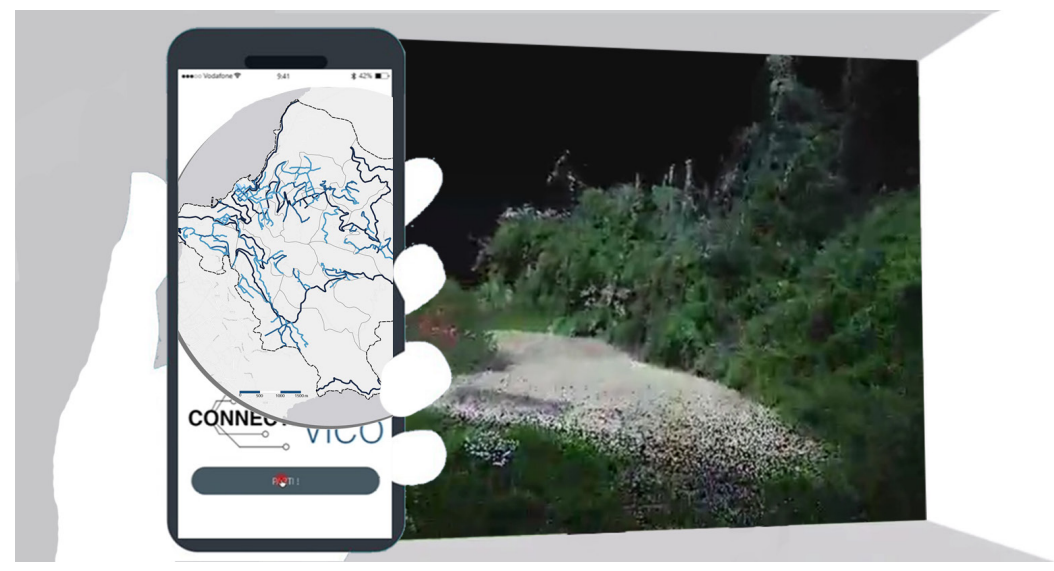




\section{Premesse}

Nel 2020 molte delle attività umane si sono fermate a causa della pandemia. Le drastiche restrizioni alla mobilità e il distanziamento fisico hanno inciso soprattutto sulle fasce più deboli della popolazione, non sostenute da adeguate risorse economiche e competenze digitali, avvezze a perpetuare rapporti fisici tra persone, modi di vivere e culture locali.

Di fatto la pandemia ha indotto l'accelerazione di un processo che in Italia attecchiva lentamente, ossia quello della digitalizzazione. Tant'è che il report italiano 2020 sull'indice di digitalizzazione dell'economia e della società (DESI [I]) sottolinea come "I'attuale pandemia di Covid- 19 ha dimostrato quanto le risorse digitali siano diventate importanti [...] e come le reti e la connettività, i dati, l'intelligenza artificiale e il supercalcolo, come pure le competenze digitali di base e avanzate, sostengano le nostre economie e società".

Indubbiamente, il complesso dei sistemi computazionali artificiali e le connessioni in rete stanno assumendo un ruolo strategico nel definire modalità di conoscenza e comunicazione; essi, tuttavia, devono tenere conto delle esigenze poste da utenti diversificati.

Non a caso i goal e i target dettati dall'Agenda 2030 sottolineano, tra l'altro, il potenziamento e la promozione dell'inclusione sociale, la formazione tecnologica e dell'informazione e l'accesso a servizi di base adeguati.

II lavoro qui presentato si colloca nell'ambito di una ricerca più ampia [2] [D'Auria, Diana 2020] che mira a definire una metodologia multiscalare che analizza territori ad alte potenzialità culturali e paesaggistiche, ma in crisi identitaria. Operativamente, ciò si traduce anche nell'acquisizione critica di dati utili all'individuazione di manufatti che si prestano a diventare luoghi di condivisione e promozione dei territori e, nel contempo, di inclusione multigenerazionale per l'educazione consapevole al digitale.

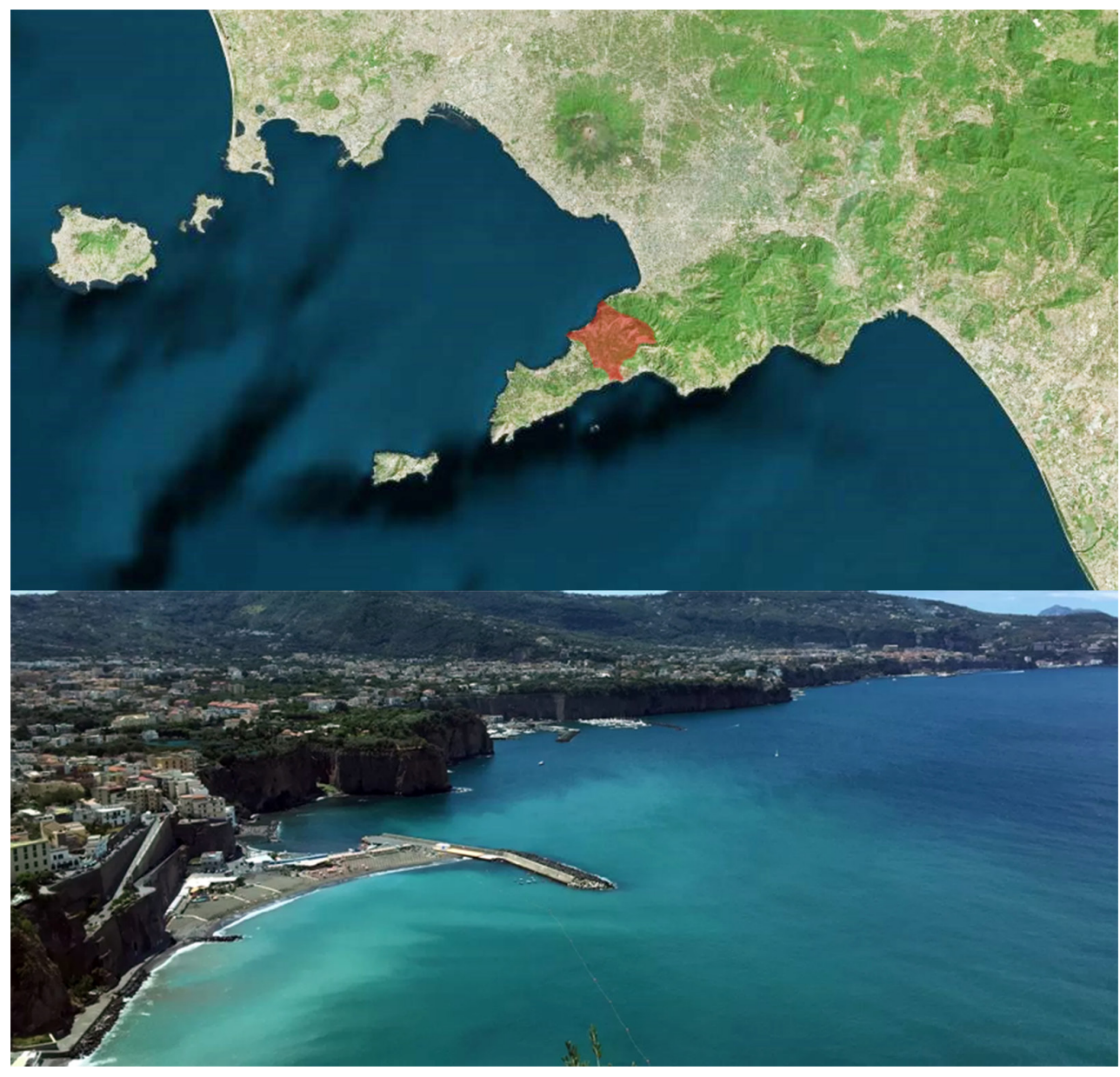


Fig. 2. Da sinistra: una veduta settecentesca di Vico Equense (Pacichelli, I 703); foto panoramica con individuazione di alcuni casali, oggi mministrativamente frazioni, posti sui crinali delle colline.

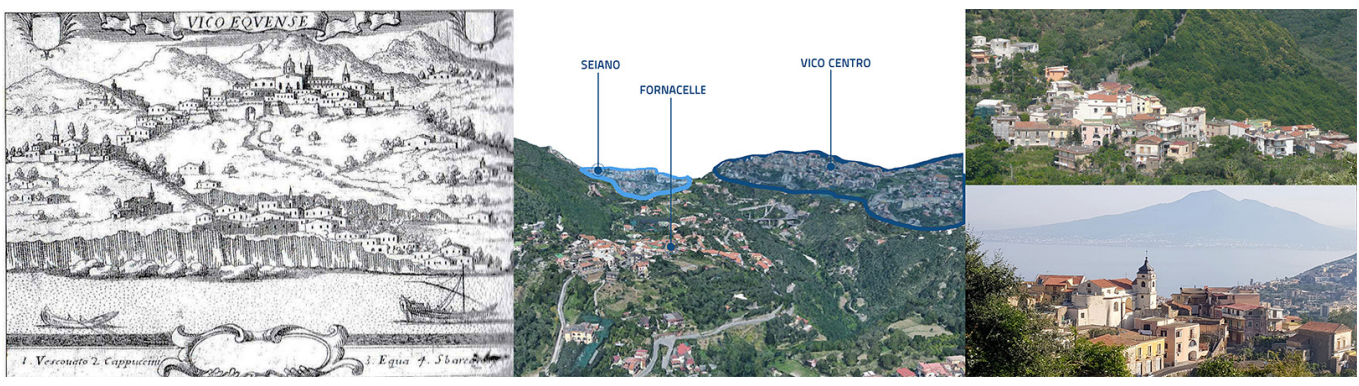

\section{La crisi identitaria dei territori rurali. il caso studio di Vico Equense}

In quest'ultimo anno le diffuse problematiche sanitarie hanno determinato anche una diversificata modalità di fruizione dei territori, favorendo in molti casi le aree interne rispetto alle aree costiere, più densamente abitate e interessate da una concentrazione turistica che configge con il necessario distanziamento. Ma principalmente hanno evidenziato sia la necessità di potenziare le competenze digitali, sia di individuare processi che contribuissero a valorizzarne l'identità. Quest'ultima ha una duplice natura: è legame, radice col passato e con la propria storia, ma allo stesso tempo è mutamento, capacità di adattamento; essa denota un processo di costruzione di significato fondato su un attributo culturale o una serie di attributi culturali in relazione tra loro, che assume un'importanza prioritaria rispetto ad altre fonti di senso [Castells 2004].

II territorio del comune di Vico Equense ben si presta a sperimentare una metodologia fondata sulla ibridazione di tecniche diversificate di acquisizione delle informazioni e di comunicazione, per descrivere le peculiarità dei luoghi partendo dal loro tessuto connettivo e orientando quei percorsi di conoscenza che, con l'aiuto della rappresentazione digitale, si dispiegano nello spazio e nel tempo, tra materiale e immateriale [Ortiz, Matas 2009].

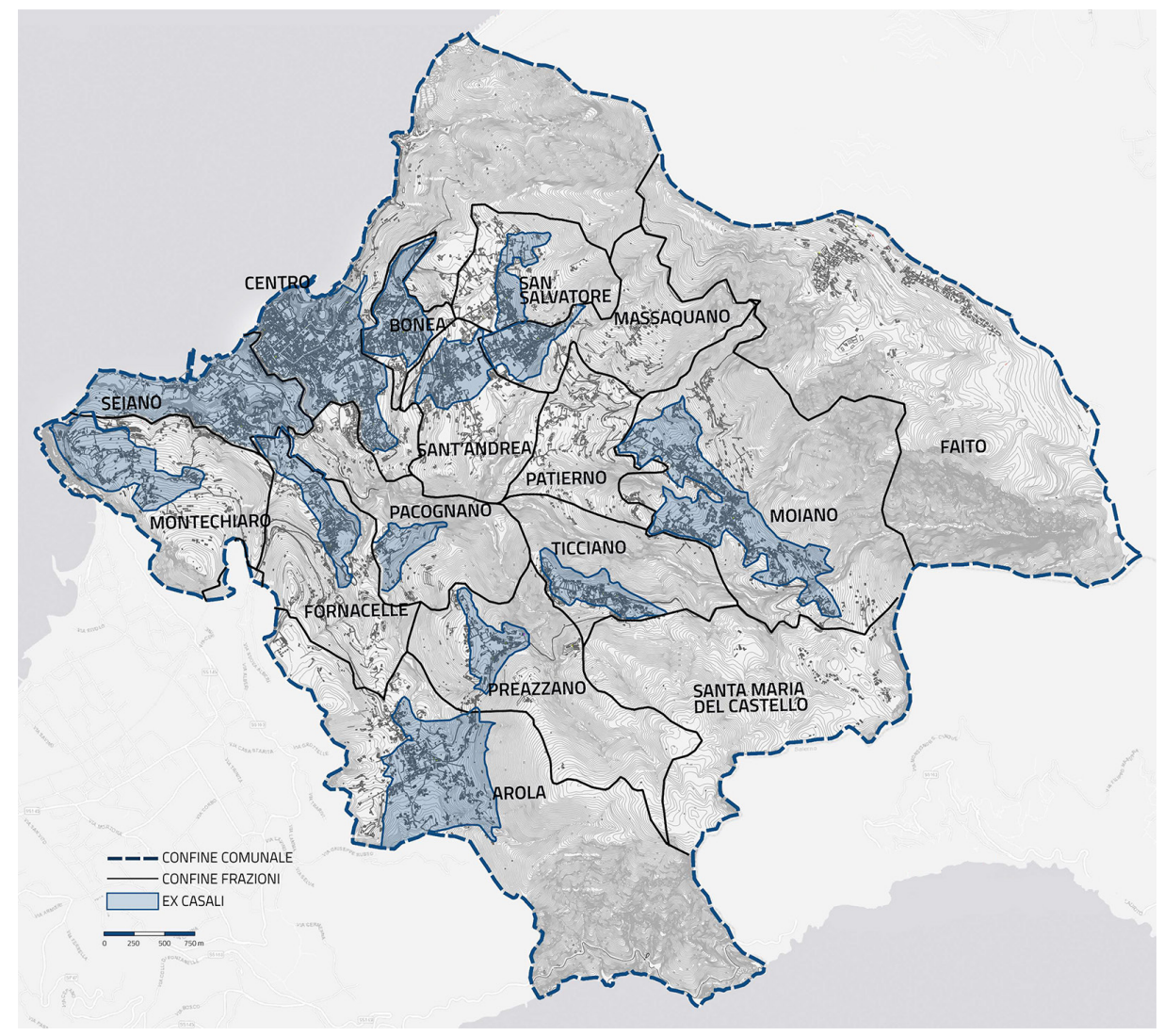

Fig. 3. Territorio comunale con individuazione delle attuali frazioni e dei casali storici, su base Carta Tecnica Regionale (2004-2005). 
Fig. 4. Da sinistra: uno scorcio panoramico dal sentiero degli Del; un gradonata di origine Medioevale nel casale di Massaquano, una vista dal (foto S. D'Auria).
Con una superficie di quasi 30 chilometri quadrati,Vico Equense è il più vasto comune della penisola sorrentina, Le sue caratteristiche geografiche, storiche, economiche e sociali, infatti, sono confrontabili in parte con quelle di molti piccoli centri rurali, dall'orografia articolata che giunge fino al mare [Fino 200 I]. Non a caso il suo territorio si presenta prevalentemente collinare, con zone che arrivano anche a un'altezza massima di oltre 1.400 metri, per poi scendere fino al mare nell'area costiera in cui si concentra il maggior flusso turistico (fig. I). Tralasciando in questa sede la descrizione della sua evoluzione storica, che ha peraltro lasciato tracce anche archeologiche di grande interesse [3], è opportuno considerare che gli insediamenti si sono sviluppati a macchia di leopardo, come efficacemente descritto da un autore anonimo nella veduta settecentesca (fig. 2), contenuta nell'opera di Giovan Battista Pacichelli dal titolo II Regno di Napoli in prospettiva [Pacichelli I 703]; in essa tra l'altro l'autore ha voluto graficamente enfatizzare gli edifici religiosi dei casali rappresentati, quasi a sottolineare gli elementi di riconoscibilità e caratterizzazione di ognuno di tali luoghi [4].

Infatti, nel corso dei secoli la popolazione si è distribuita nelle aree più interne prevalentemente per motivi difensivi, dapprima in piccoli insediamenti rurali e successivamente, già con la colonizzazione romana, in centri più strutturati (fig. 3), aventi tradizioni e forme produttive anche molto diverse, determinate in buona parte dal contesto ambientale e dal clima; tra questi insediamenti si è venuta a creare una rete di percorsi a carattere rurale che li collegava non solo tra loro ma anche con il nucleo abitato prossimo al mare, per consentire il commercio dei prodotti locali - formaggi, vino, olio, agrumi - nonché della richiestissima 'neve del Faito' [5].

Lungo questi percorsi, battuti nel corso dei secoli da contadini, viaggiatori, invasori, pirati, sorgevano architetture monastiche, mulini, opere di grande significato per la memoria collettiva, oggi in gran parte allo stato di rudere. Alcuni di questi percorsi, come il famoso 'sentiero degli Dei', possono essere oggi utilizzati solo da esperti di trekking, anche per le condizioni di notevole difficoltà e rischio, molti altri invece hanno consolidato nel tempo la loro funzione di collegamento tra nuclei sempre più densamente edificati (fig. 4).

Con la costruzione ottocentesca delle prime strade carrabili e ferrate, e la conseguente espansione insediativa della fascia edificata prossima al mare [6], la natura dei casali è andata lentamente trasformandosi, subendo un progressivo depauperamento delle specifiche connotazioni insediative [Jalongo 1994], insieme a quella rete di relazioni fisiche che ne avevano supportato, fin dalla loro origine le specifiche caratteristiche locali (fig. 5).
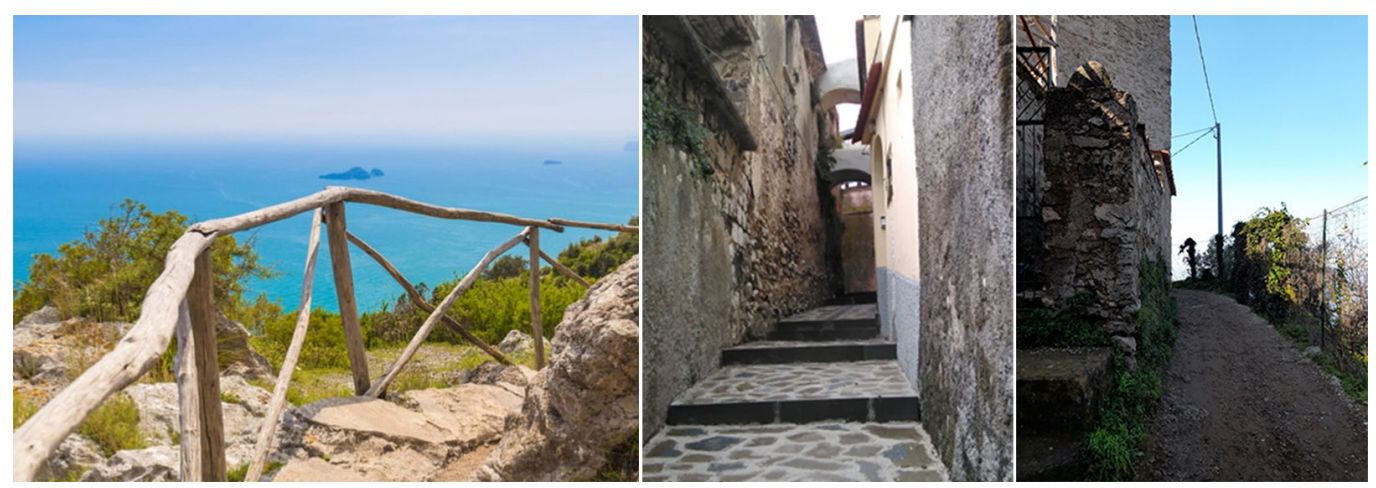

\section{Ambienti digitali per la conoscenza e la valorizzazione identitaria}

L'analisi dei percorsi, intesi come alvei, contenitori di flussi di percorsi e cose [Caniglia Rispoli 2003, p. 47], diventa dunque un fondamentale tassello per riscoprire le peculiarità degli originari insediamenti, evidenziando anche l'esigenza di mettere a sistema un processo conoscitivo teso a orientare coerenti e prioritarie iniziative progettuali di fruizione ampliata, con l'ausilio di strumenti digitali, hardware e software, utili anche a svolgere un'azione educativa tra le giovani generazioni, per meglio comprendere i luoghi e la loro memoria [Papa, D'Auria 2020] fatta anche di tradizioni tipicamente rurali perché, come scriveva in proposi- 

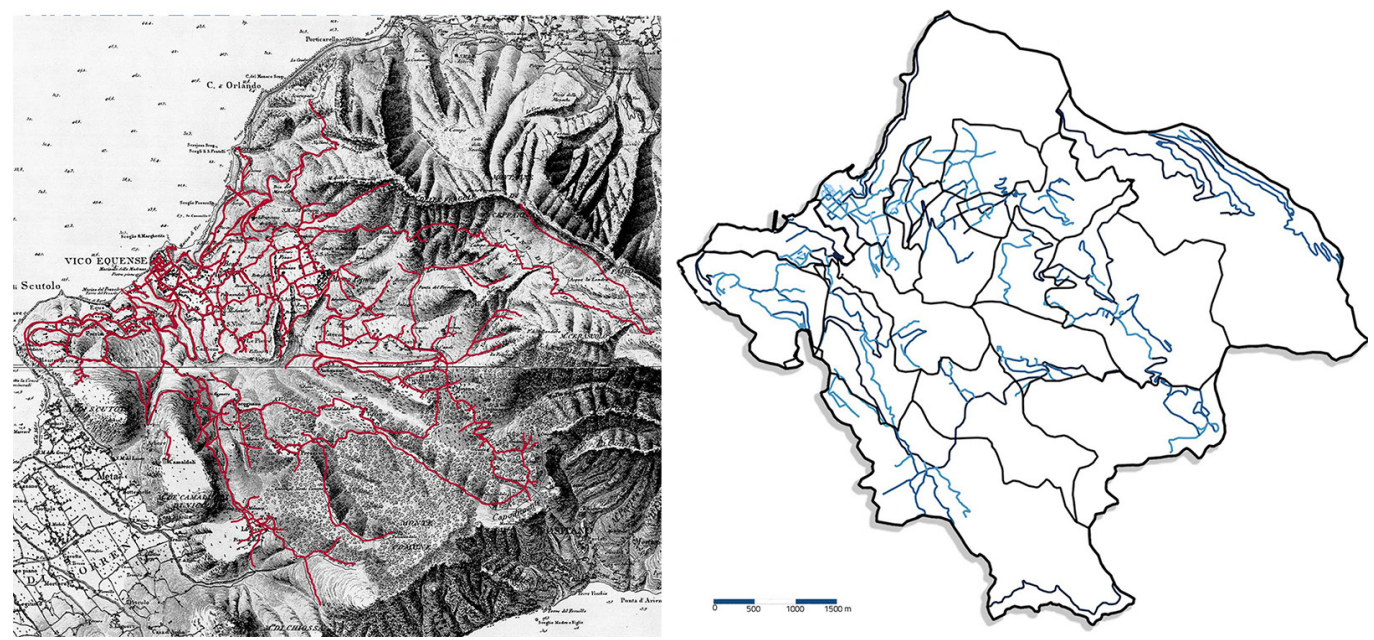

to Cristian Norberg-Schulz (1996) "ogni luogo possiede la sua peculiare identità ed è compito dell'uomo comprenderla e averne cura, attraverso un processo che evidentemente non avrà mai fine. Potremmo anche dire che dobbiamo cooperare a che il luogo trovi sé stesso, nel corso della storia. Ogni epoca svela alcune delle qualità del luogo e ne vela delle altre". È stato prioritariamente necessario elaborare una scheda di rilievo speditivo dei singoli percorsi contenente una serie di informazioni che consentono di capirne le caratteristiche morfologiche, ma anche le criticità e le potenzialità di fruizione. Essa è divisa in tre parti, con una progressiva definizione di informazioni contenenti, ad esempio, informazioni generali di natura topografica, geometrica e altimetrica, foto esplicative, stralcio planimetrico, note bibliografiche, dati sulla tipologia e stato di conservazione della pavimentazione, qualità percettive. Il codice di riferimento presente in ogni scheda e le informazioni contenute consentono di popolare una banca di dati georiferiti, con la definizione di un suo segmento fondamentale, il SIP (Sistema Informativo dei Percorsi). II geodatabase, oltre a essere strutturato in modo da razionalizzare la gestione e l'aggiornamento delle informazioni, contiene dunque informazioni di diverso formato (fig. 6), utili anche per realizzare ricerche complesse ed elaborare mappe tematiche [Gaiani 20I2].

II percorso presentato come caso campione per questa ricerca è il sentiero denominato Meta-Fornacelle. Lungo circa 750 metri, esso connette il limitrofo comune di Meta di Sorrento con l'antico casale di Fornacelle (fig. 7).
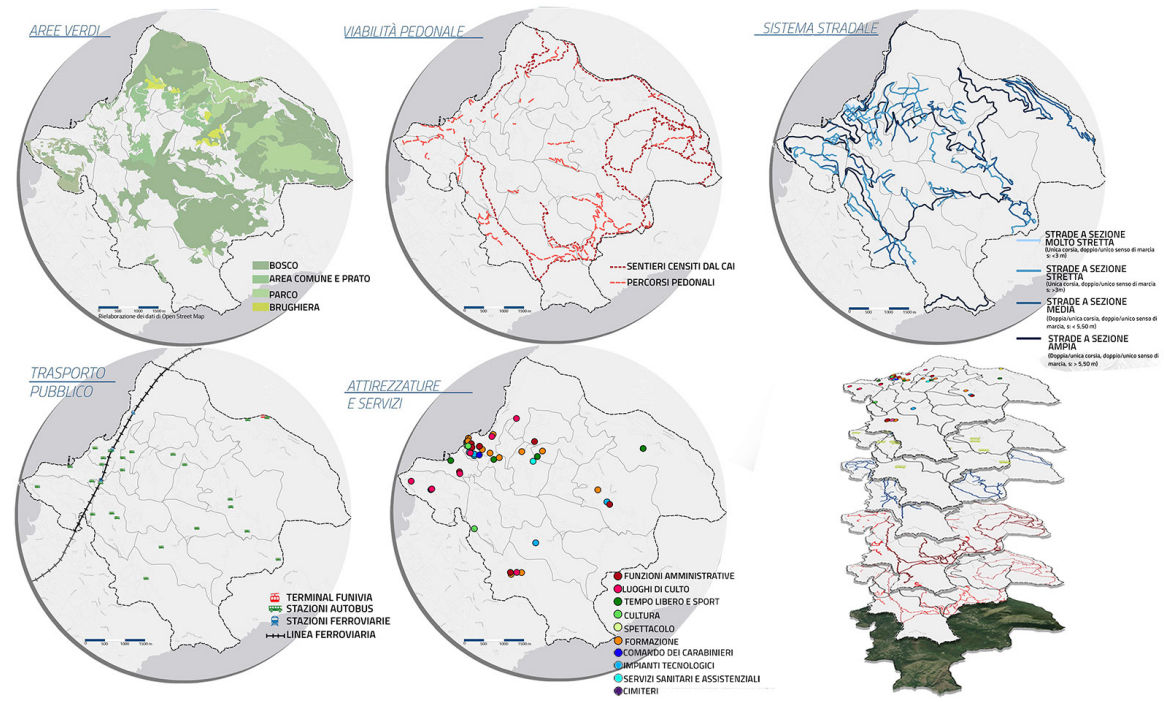
Fig. 7. Individuazione di un entiero esemplificativo della metodología adottata
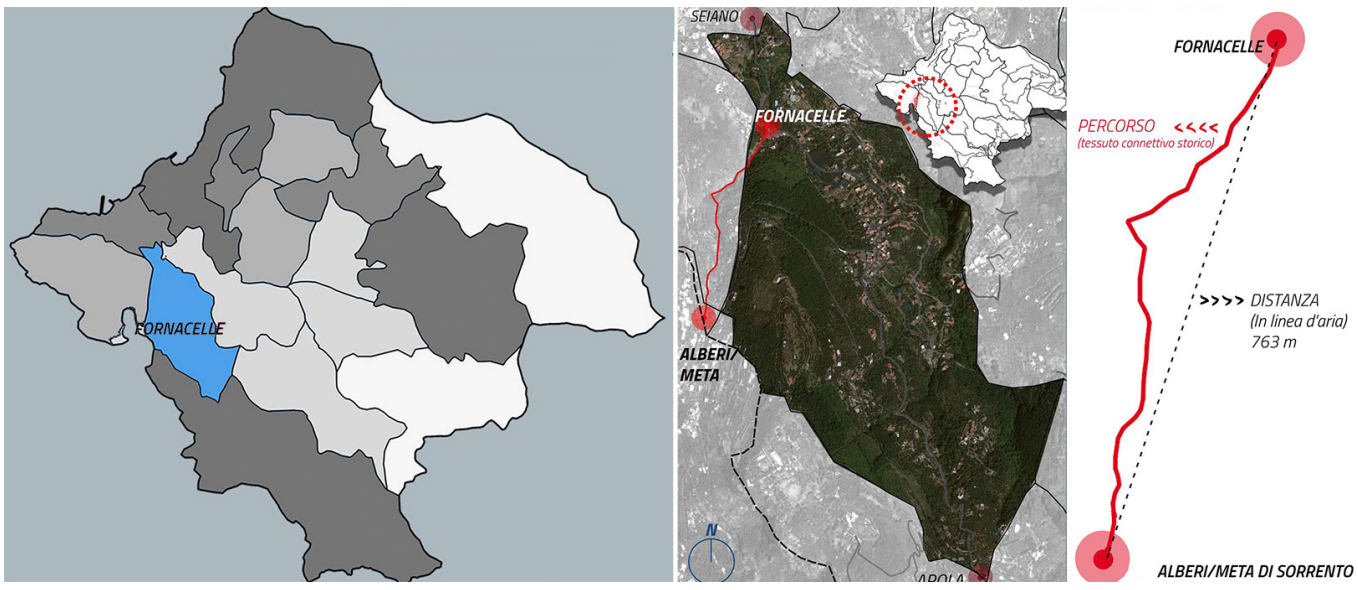

Una proposta di app per la conoscenza e la fruizione

La veicolazione delle informazioni è diventata di primaria importanza per le istituzioni e per soddisfare le esigenze di una utenza ampia e diversificata.

Nell'ambito della ricerca una delle strategie messe a punto per il perseguimento degli obiettivi di valorizzazione è stata la creazione di un applicativo software, open source e user friendly, per device mobili.

L'app, denominata ConnectingVICO, è stata progettata per interagire sia con i percorsi sentieristici, sia con la creazione di hub culturali - la cui descrizione non è oggetto del presente contributo - da realizzare rigenerando edifici pubblici attualmente non utilizzati.

Come si può vedere nelle sequenze in figura 8, essa consente di scegliere il luogo di interesse, individuabile anche attraverso la posizione GPS dello smartphone, e successivamente di "entrare" all'interno del percorso di riferimento o dell'hub culturale al quale rimanda [lppoliti 20।8].

Sono dunque presenti informazioni sulle caratteristiche del percorso (lunghezza, tipologia di tracciato, differenza di quota, pendenze, punti di interesse, tempo presunto di percorrenza a seconda della tipologia di utente, notizie storiche, ecc.); è inoltre possibile personalizzare la propria esperienza con punti di interesse, fotografie e video prodotti durante il percorso, nonché interagire con i QR-code presenti sui totem informativi installati lungo il tracciato

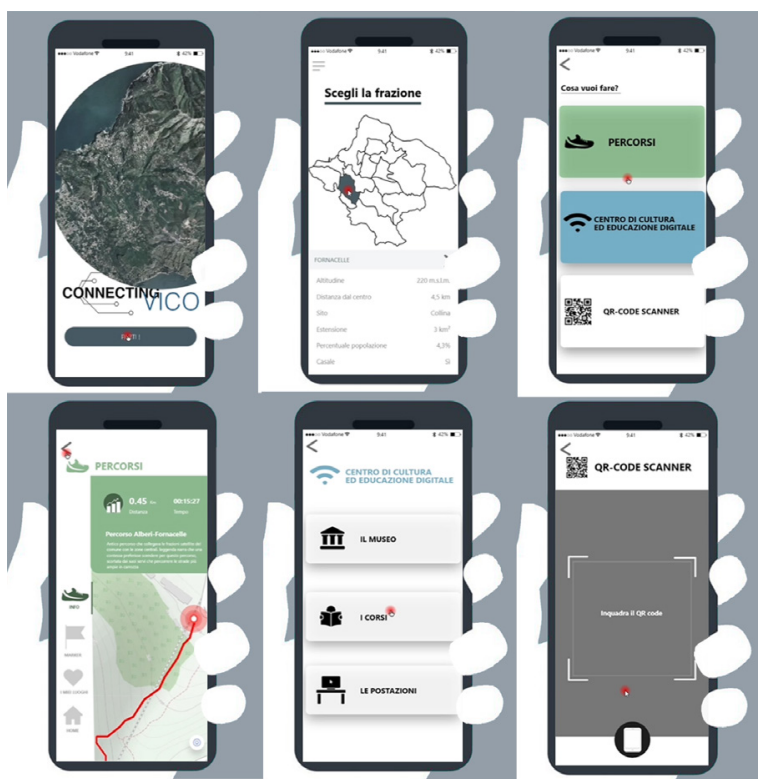


Fig. 9. Alcuni degli output grafici presenti nell'app. Analisi plano-altimetrica del percorso e punti. di criticità o interesse paesaggistico.
Fig. 10. Fotomodellazione di un tratto del sentiero Fornacelle-Meta e nuvola di punti.

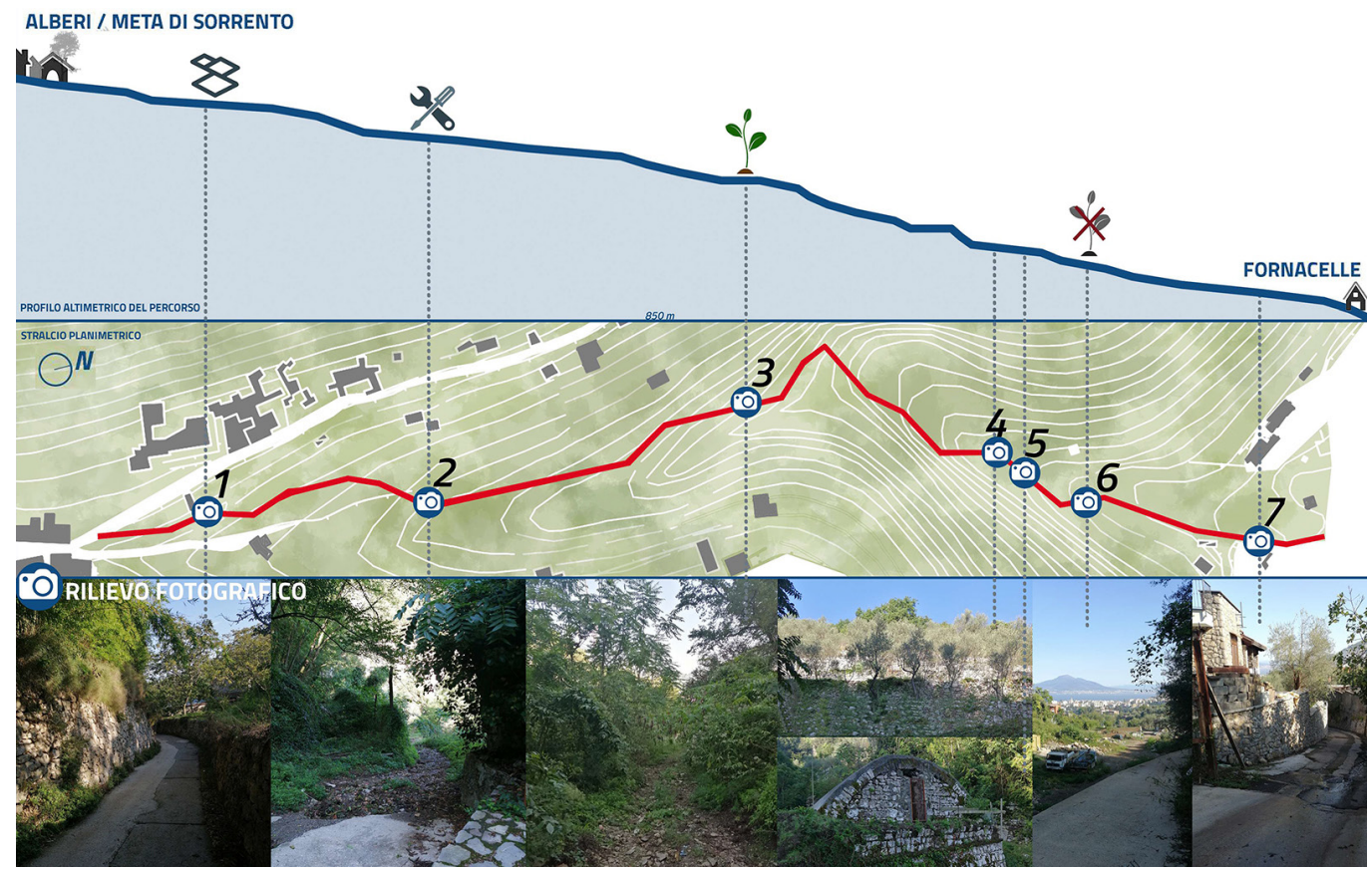

(fig. 9). È anche possibile, come anticipato, usufruire dei servizi offerti dall'hub culturale di riferimento per quel determinato territorio, per il quale sono previsti percorsi esperienziali di realtà immersiva. Sicché la comunicazione virtuale si presenta come un 'potenziamento' della corporeità, ampliandone i limiti [lppoliti 2018]. Pertanto, il modello virtuale del percorso esemplificato in questo contesto è stato elaborato mediante consolidate procedure di modellazione image-based da rilievo fotogrammetrico aereo con drone (fig. I0). In particolare, le immagini sintetizzano l'attività di rilievo di un tratto del sentiero Fornacelle-Meta, ossia del segmento più significativo dal punto di vista naturalistico, compreso tra i punti 4 e 6 individuati nello stralcio planimetrico.

Particolare attenzione nella pianificazione delle operazioni di volo è stata prestata all'interferenza dell'aeromobile con alberi e arbusti che avrebbero potuto compromettere l'intero rilievo, o determinare comunque eccessive elaborazioni di filtraggio del rumore.

II modello è stato impiegato per le applicazioni di realtà immersiva (figg. I I, I2) attraverso software e hardware dedicati. L'idea è quella di consentire la percorrenza virtuale permettendo così anche alle persone distanti di godere della bellezza dei luoghi.
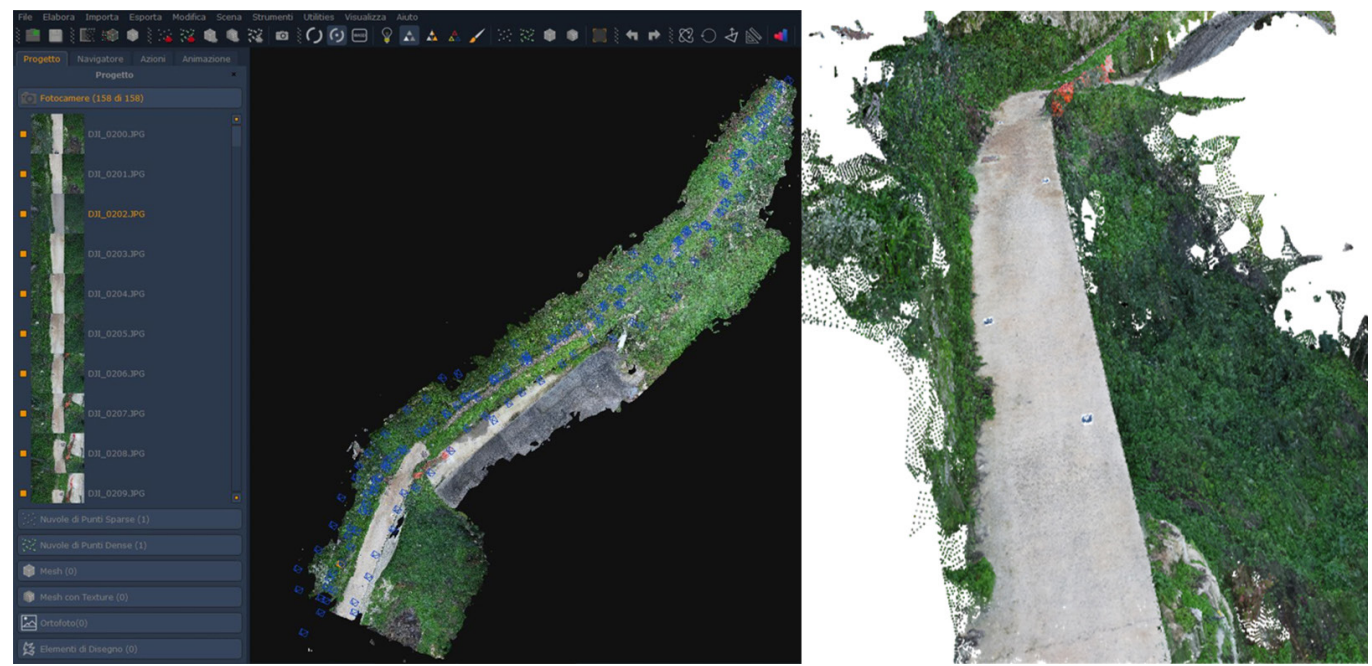


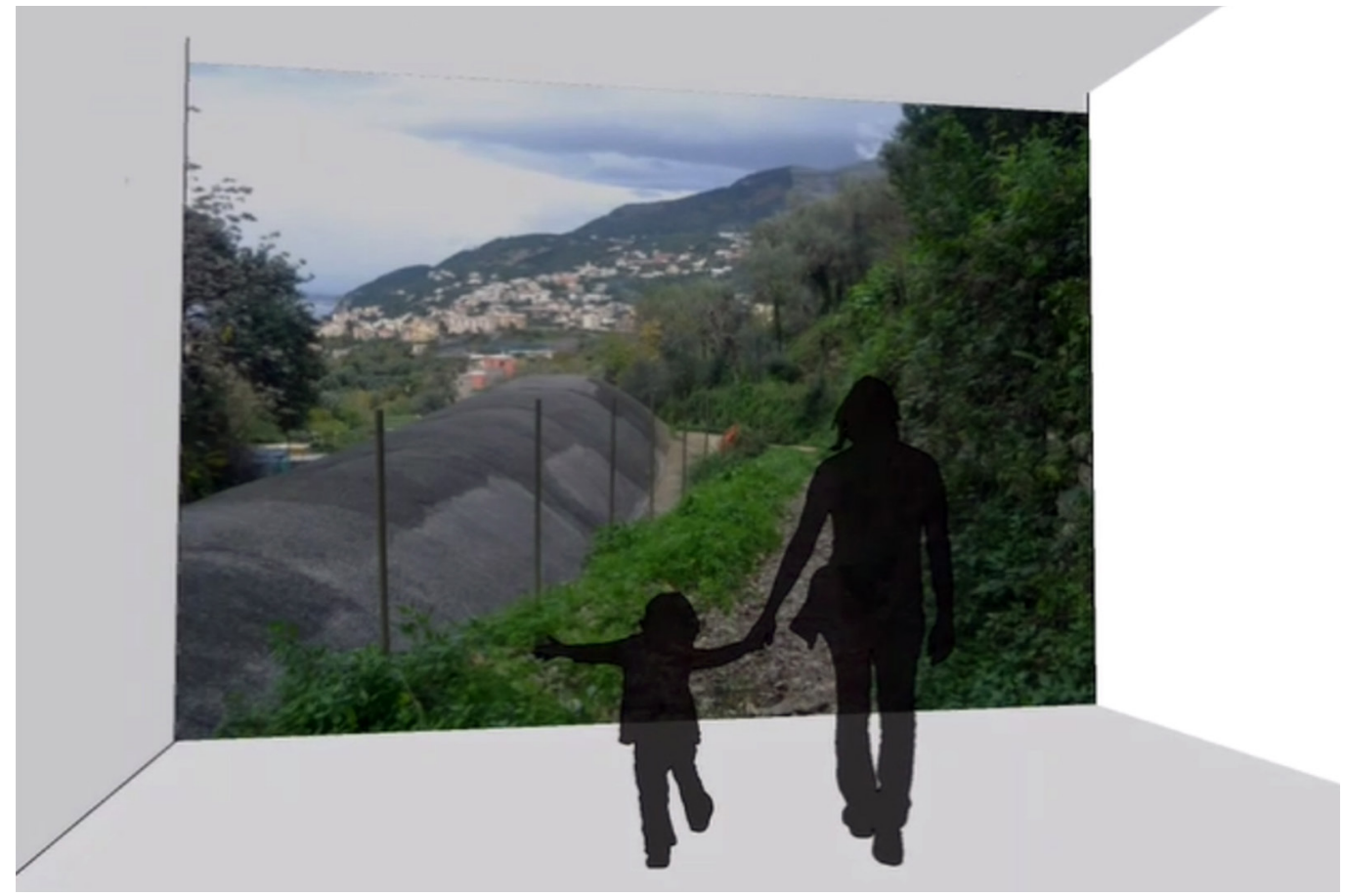

\section{Conclusioni}

Il lavoro presentato affronta alcuni aspetti significativi per il settore del Disegno, relativi a un tema ampio come quello della individuazione di processi e artefatti visuali per la valorizzazione di alcuni territori ad alte potenzialità, ma in crisi identitaria. Vico Equense rappresenta uno dei tanti e complessi scenari del nostro Paese ricchi di storia, cultura, bellezze paesaggistiche, emergenze architettoniche, archeologiche e urbanistiche in cui le attività proprie del Disegno - in sinergia con altri Settori - possono contribuire a valorizzarne aspetti (materiali e immateriali) anche apparentemente eterogenei.

La metodologia adottata vede la definizione di processi multiscalari di rigenerazione sostenibile e partecipata che si dispiegano nel dominio digitale. Ciò si traduce nell'acquisizione consapevole di dati e nella loro critica elaborazione allo scopo di individuare anche edifici idonei a diventare luoghi di condivisione e promozione delle connotazioni identitarie e, nel contempo, di inclusione multigenerazionale, anche per l'educazione consapevole al digitale. Evidentemente tale processo non richiede solo la padronanza di strumenti hardware e software dedicati, ma necessita di sperimentare modalità comunicative nuove e linguaggi ibridati, utili per ristabilire un rapporto forte con i luoghi della memoria locale.
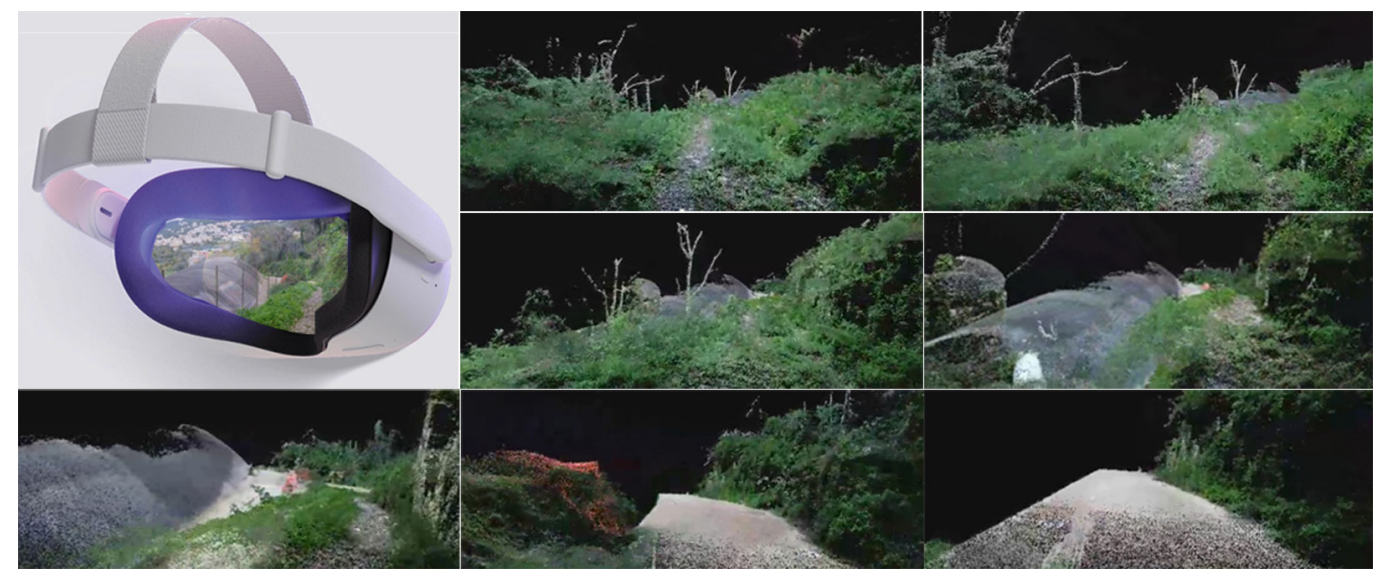


\section{Note}

[I] Secondo il Digital Economy and Society Index 2020 (DESI), l'ltalia si colloca al 24 tra i 28 stati membri.

[2] La ricerca è maturata nell'ambito del PON Ricerca e Innovazione 20 I4-2020, Asse I Investimenti in capitale umano, Awiso AIM - Attrazione e Mobilità Internazionale, Linea I.

[3] Lo studio completo viene svolto nell'ambito del REMLab (Laboratorio di Rilievo e Modellazione) del Dipartimento di Ingegneria Civile, Edile e Ambientale dell'Università di Napoli Federico II, e ha coinvolto anche alcuni tesisti.

[4] Fino al XIX secolo i casali, denominati amministrativamente in età moderna frazioni, erano I 3: Bonea, Massaquano, Moiano, Ticciano, Prezzano, Arola, Fornacelle, Pacognano, Seiano, Montechiaro, San Salvatore, Sant'Andrea, Vico.

[5] Un tempo il Monte Sant'Angelo, a oltre 1400 m slm, era ricco di 'neviere', profonde buche dove, nel periodo invernale, veniva conservata la neve. Le 'neviere' venivano infatti riempite con strati alterni di neve e foglie di faggio che proteggevano la neve accumulata fino a quando questa veniva cavata in blocchi regolari che, avvolti in panni di canapa, erano trasportati nei luoghi di destinazione, per alleviare la calura estiva.

[6] La realizzazione della nuova strada sorrentina rappresentò la spinta decisiva per avviare la costruzione di una strada rotabile che scendeva fino alla spiaggia. La nuova strada fu costruita negli anni | 849- 850 dall'ingegner Agresti del demanio regio.

\section{Riferimenti bibliografici}

Caniglia Rispoli C. (2003). Come rappresentare i percorsi urbani. In L. M. Papa (a cura di). Disegno e disegni dei percorsi urbani. Napoli: Cuen.

Castells M. (1998). The Information Age: Economy, Society and Culture. In Environment and Planning B: Planning and Design, 25(4), pp 63I-636. Milano: Egea.

D'Auria S., Diana L. (2020). The regeneration of public heritage estate in Campania: an assessment approach. In Sustainable Mediterranean Construction. Land culture, research and technology, I I, pp. 35-40.

Dondona C. A., Piemonte I. (2019). Turismo montano e valorizzazione del patrimonio escursionistico regionale. II Tour del Monviso. In EyerReg, vol. 9, n. 4, pp. $172-178$.

European Commission (2020). Indice di digitalizzazione dell'economia e della società (DESI).

Fino L. (200 I). Da Castellammare a Massa. Vedute e costumi della costiera sorrentina. Disegni, acquerelli e stampe dal XVI al XIX secolo. Napoli: Grimaldi \& C.

Gaiani M. (20I2). Creare Sistemi Informativi per studiare, conservare, gestire e comunicare sistemi architettonici e archeologici complessi. In DisegnareCon, vol. 5, n. 10, pp. 9-20.

Ippoliti E., Casale A. (20।8). Rappresentare, comunicare, narrare. Spazi e musei virtuali tra riflessioni e ricerche. In A. Luigini, C. Jalongo G. (1994). Città e casali della penisola sorrentina. Roma: Officina Edizioni.

Norberg-Schulz C. (1996). Architettura: presenza, linguaggio e luogo. Milano: Skira.

Ortiz P., Matas M. (2009). Experiences about fusioning 3D digitalization techniques for cultural heritage documentation in Cáceres wall (Spain). In 3D-ARCH '2009, ISPRS, vol. XXXVIII-5/MI.

Pacichelli G. B. ( 1703). Il Regno di Napoli in prospettiva diviso in dodeci provincie. Napoli: nella stamperia di Michele Luigi Mutio.

Pancioli (a cura di). Ambienti digitali per l'educazione all'arte e al patrimonio, pp. I28, I 5 I. Milano: FrancoAngeli.

Papa L. M., D'Auria S. (2020). Rilievo e modellazione digitale: un percorso critico per la valorizzazione del Castello di Ischia. In J. Navarro Palazón, L. J. García-Pulido (a cura di). Defensive Architecture of the Mediterranean, International Conference on Fortifications of the Mediterranean Coast, vol. X, pp. 407-4I4. Granada: Universidad de Granada.

Zola L. E. (2019). Percorsi di valorizzazione dei sentieri alpini e trekking someggiato. In AA.V. (a cura di). Beni e risorse culturali delle comunità alpine. Fra storia e valorizzazione, pp. I45- 155. Cherasco: CISIM.

\section{Autori}

Saverio D’Auria, Università degli Studi di Napoli Federico II, saverio.dauria@unina.it,

Lia Maria Papa, Università degli Studi di Napoli Federico II, Impapa@unina.it

Per citare questo capitolo: D'Auria Saverio, Papa Lia Maria (2021). Connessioni (im)materiali per una rigenerazione sostenibile/(IM)Material connections for a sustainable regeneration. In Arena A., Arena M., Mediati D., Raffa P. (a cura di). Connettere. Un disegno per annodare e tessere. Linguaggi Distanze Tecnologie. Atti del $42^{\circ}$ Convegno Internazionale dei Docenti delle Discipline della Rappresentazione/Connecting. Drawing for weaving relationship. Languages Distances Technologies. Proceedings of the $42^{\text {th }}$ International Conference of Representation Disciplines Teachers. Milano: FrancoAngeli, pp. I 545-1592. 


\title{
(IM)Material Connections for a Sustainable Regeneration
}

\author{
Saverio D'Auria \\ Lia Maria Papa
}

Abstract

The paper addresses some important aspects for the Drawing sector. They deal with the theme of valorisation of some rural territories, where the present identity crisis was exasperated by the current pandemic situation. Covid- 19 affects the weaker section of society, who were not supported by sufficient economic resources and digital skills, and who were accustomed to perpetuate way of living and local cultures through interpersonal relationships.

The case study presented is related to a town in the Sorrento peninsula and it is placed in a wider research, that aims to define a multi-scalar approach in order to experience and participate in the digital domain. The pathway study is considered as riverbeds, i.e container of flow paths and flow stuff. The path analysis is a fundamental element to rediscover the original settlements peculiarity. It also emphasizes the necessity to systematize a cognitive process, that is the guidance for a coherent, priority project initiatives of wider accessibility. To accomplish this, digital tools, hardware and software are required, because they are beneficial to educating the rising generation. Lastly the path analysis helps to understand places and the memory of the typical rural traditions.

\section{Keywords}

identity, connections, digital environment, 3D survey, multigenerational access.

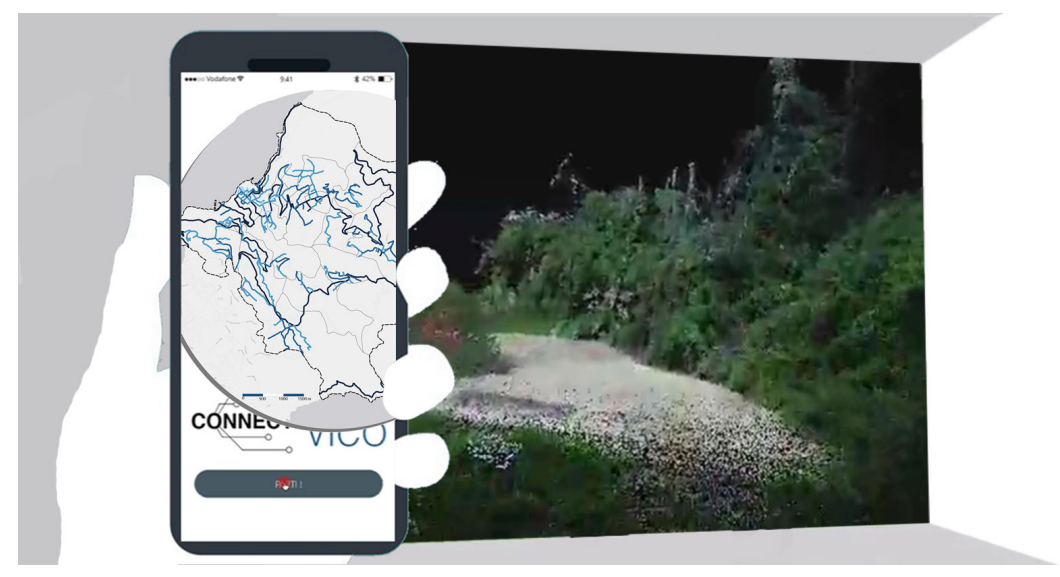




\section{Introduction}

In 2020 many human activities stopped due to pandemic. The drastic restrictions to mobility and the social distancing affected, in particular, the weaker sections of the society, who were not supported by sufficient economic resources and digital skills, and who were accustomed to perpetuate physical relationship among people, way of living and local cultures.

The pandemic has accelerated a process, that is digitization, that was taking root slowly in Italy. The Italian Report 2020 on the Digital Economy and Society Index (DESI) [I] highlights how "the current Covid- 19 pandemic proved how the digital resources have become important $[. .$.$] and how nets and connectivity, data, artificial intelligence and supercomputing,$ as the basic and advanced skills, support our economy and society".

Certainly, the complex of artificial computational system and network connections are taking a strategic role in defining modalities of knowledge and communication. However, they have to take into account of diversified users' needs.

Not surprisingly the goals and targets of Agenda 2030, by the way, highlight the strengthening and the promotion of social inclusion, technology training, information and the access to appropriate base services.

The work presented here is placed in a wider research, that aims to define a multi-scalar approach in order to analyse the high potentiality cultural and landscaped territories in identity crisis.

This results also in the acquisition of critical data, that are useful in the identification of manufactured goods. They could become places for sharing and for territorial promotion and, simultaneously places for multigenerational inclusion and conscientious digital education.

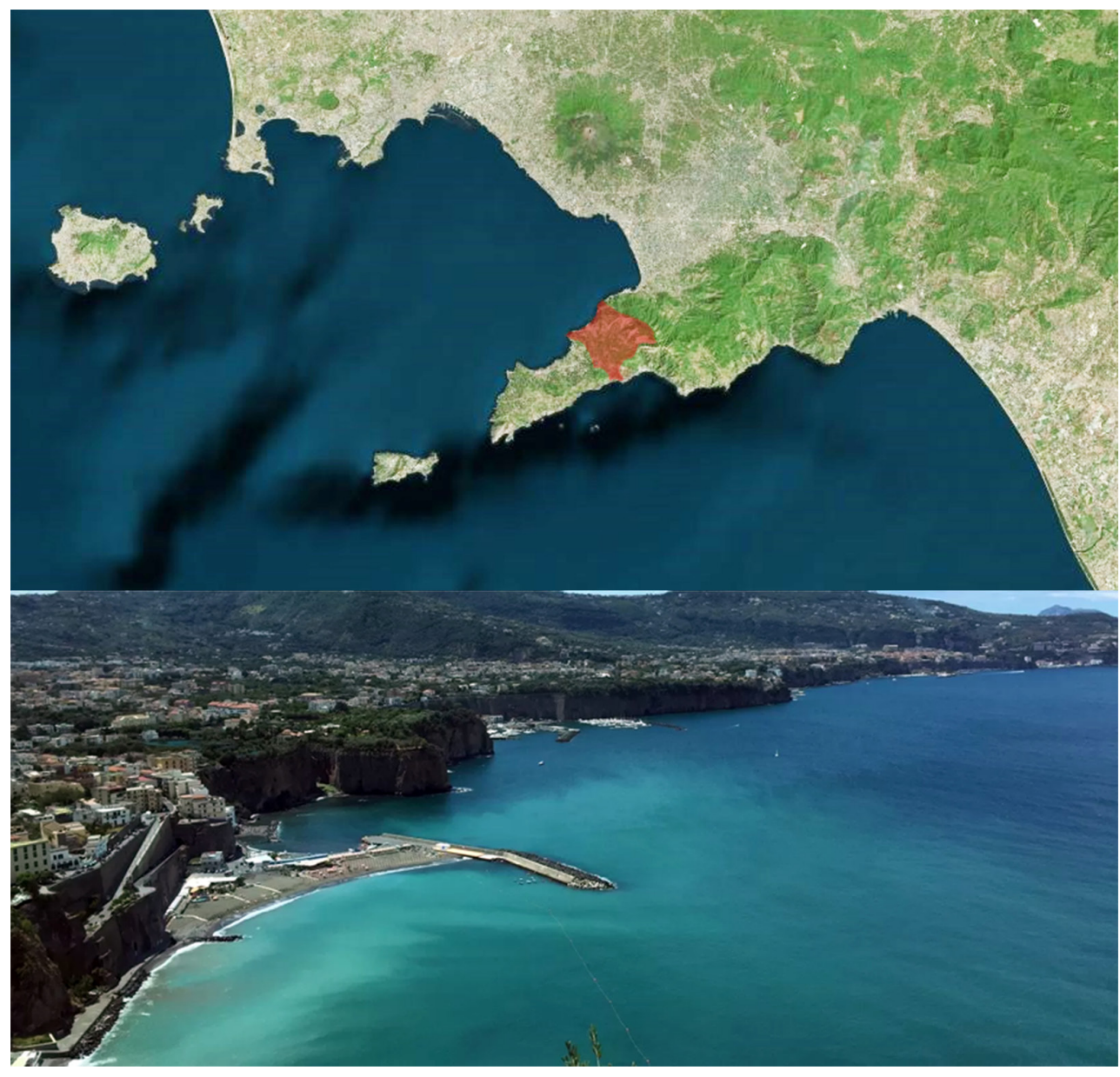


Fig. 2. From left: 18th century view of Vico Equense (Pacichelli, 1703): panoramic 703), panoramic photograph of some areas; the ridges of the hill.

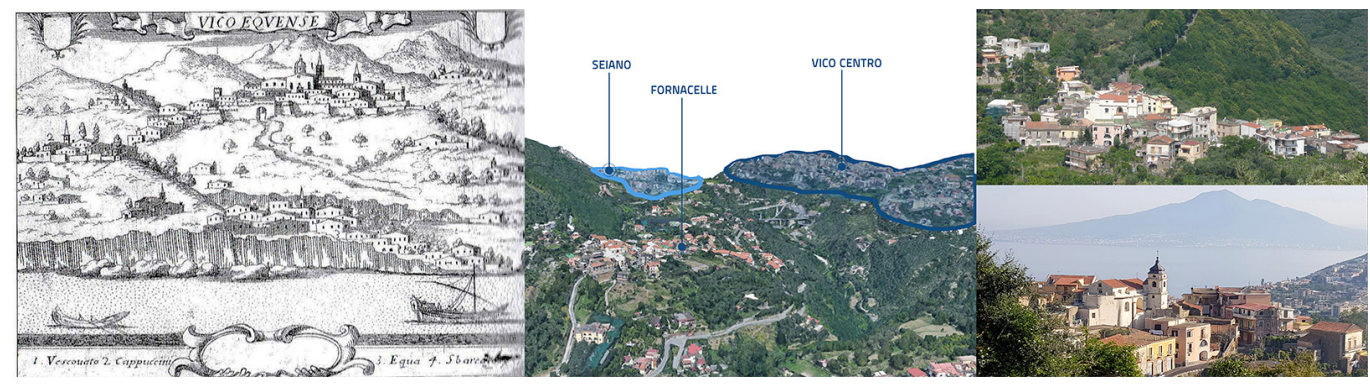

\section{Rural areas identity. the vico equense case study}

In the last year, the common health concerns also established a different access to territories, favouring in many cases the internal areas compared to the costal ones, that are densely inhabited and interested by tourist concentrate. For this reason, they require the right distancing. Principally they highlighted both the necessity to empower the digital skills, and to establish process in order to enhance its identity. This identity has a dual nature: it is a connection with the past and with its own story, but at the same time is transformation and capacity of adaptation. It denotes a process of meaning construction based on a cultural attribute or on a series of cultural attributes related to each other. This process receives a priority regarding other sources of sense [Castells 2004].

The territory of the city Vico Equense lends itself to experience a methodology, based on hybridization of different techniques to the acquisition of information and communication. This is to describe the peculiarities of each place, starting with their connective tissue and by orienting knowledge paths, that with the aid of the digital representation, unfold in space and time, among material and immaterial.

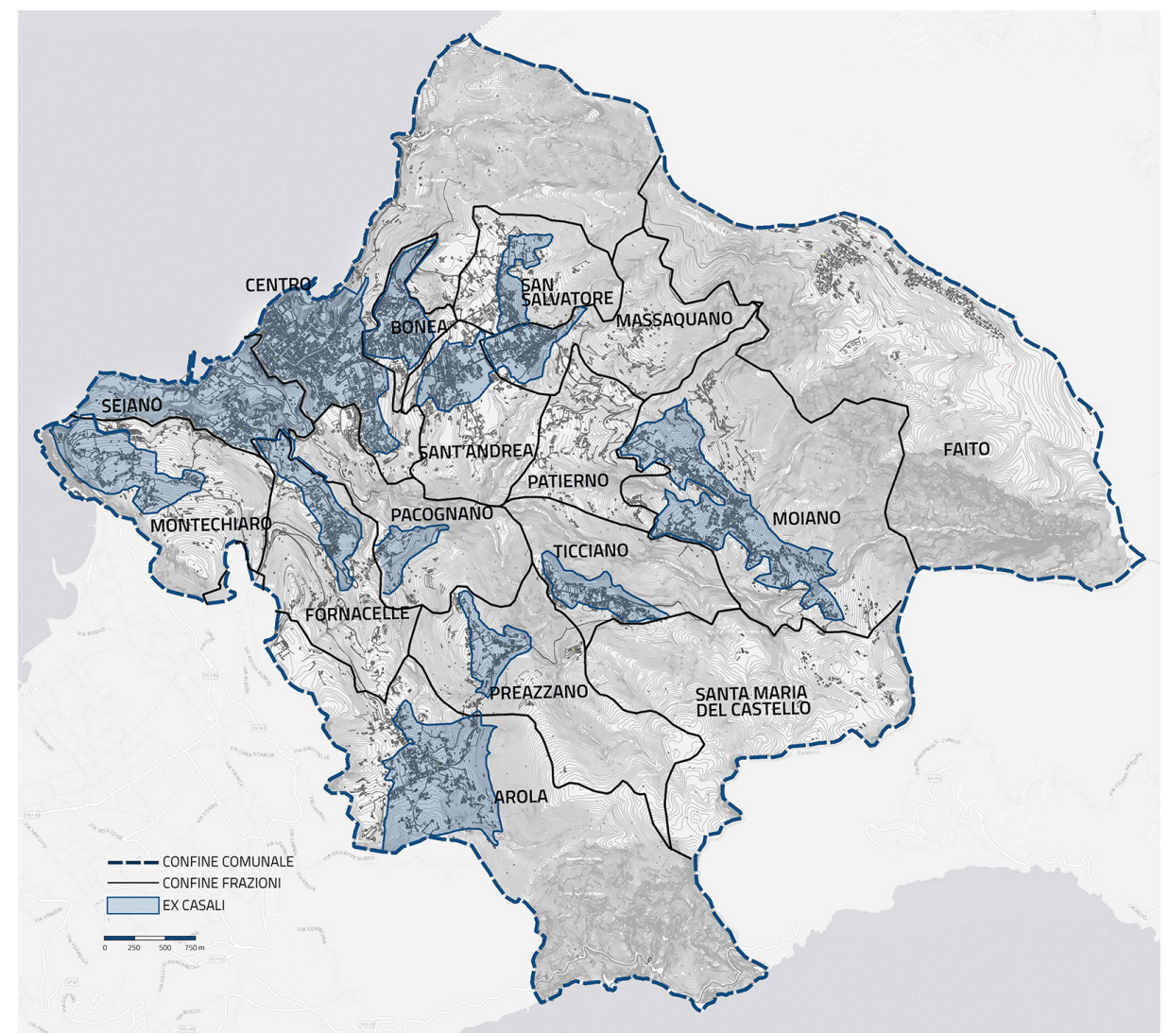

Fig. 3. Municipal area with the current districts and historical villages, based on the Regional Technical Map (2004- 2005). 
Fig. 4. From left: panoramic view of the Sentiero degli Dei; medieval terrace of Massaquano village; a view from the Sperlonga pathway (photos by S. D'Auria).
Vico Equense is the widest city in the Sorrento peninsula, with an area of $30 \mathrm{~km}^{2}$. As a matter of fact its geographical, historical, economic and social characteristics are comparable in part to those of several small rural towns from orography that reaches the sea. Its territory, not by chance, is mainly hilly with areas, that reaches a maximum altitude of 1400 metres. These areas run down to the sea in a coastal area, in which the greater flow of tourist is present (fig. I).

The description of its historical evolution is not discussed, but it is good to remember that it left also very interesting archaeological traces [2].

It is appropriate to consider that the settlements have developed a leopard spots, as described by an anonymous author in 1703 (fig. 2). This description is in the work of Giovan Battista Pacichelli II Regno di Napoli in prospettiva; the author wanted to emphasize the religious building of the represented villages in order to highlight the recognizable and distinctive element of each place [3].

As a matter of facts, during centuries population has distributed in the inner areas for defensive reasons, firstly in small rural settlements and then, already with the roman colonization, in more structured centres (fig. 3). They also had very different productive traditions and patterns, that were mostly determined by the environmental context and by the climate. A rural network of trails has been created between these settlements, that were connected not only to each other, but also with the nearest towns close to the sea. This was helpful to allow local trade- cheese, wine, oil, citrus fruits- as well as the most required "neve del Faito [4]".

Monastic architecture, mills and significant works for the collective memory were located along these paths, that had been travelled by peasants, visitors, invaders and pirates during centuries. However nowadays they are reduced to a state of ruin. Some of these paths, as the famous Sentiero degli Dei, could be walked only by hiking experts today. This is because these ways are difficult and risky. Instead, many others have consolidated their connecting function among high-density places over time (fig. 4).

Due to the $19^{\text {th }}$ century building of the first accessible roads and the consequent settlement close to the sea [5], the nature of the villages has slowly transformed. It underwent a progressive depletion of urban planning and specific local characteristics (fig. 5).
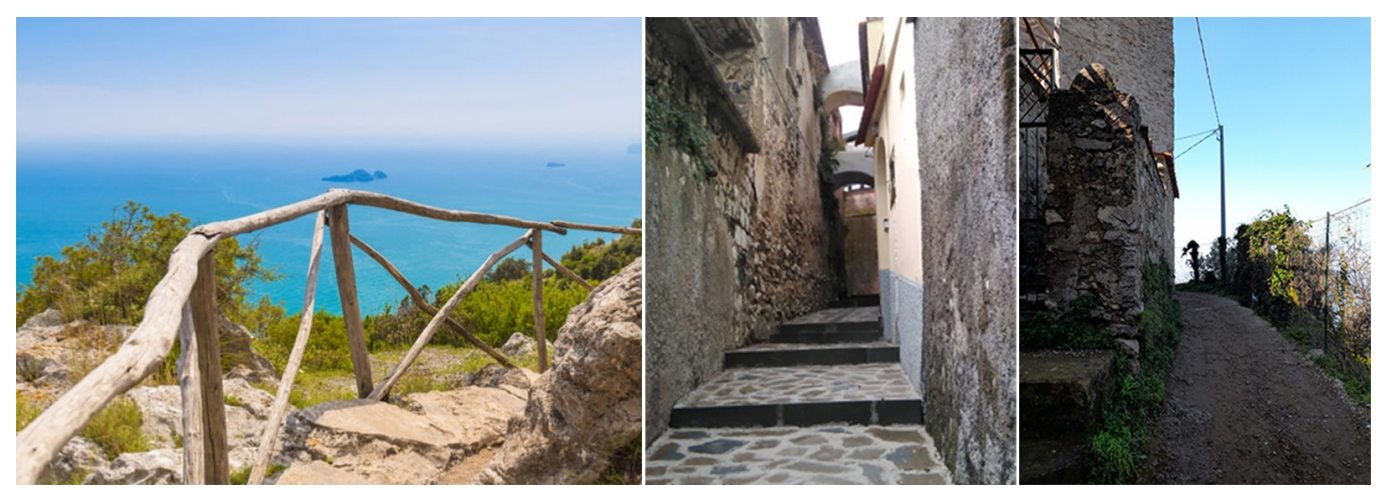

Digital environment for the identity knowledge and valorization

These paths are considered as riverbeds, i.e container of flow paths and flow stuff [Caniglia Rispoli 2003, p. 47]. The path analysis is a fundamental element to rediscover the original settlements peculiarity. It also emphasizes the necessity to systematize a cognitive process, that is the guidance for a coherent, priority project initiatives of wider accessibility. To accomplish this, digital tools, hardware and software are required, because they are beneficial to educating the rising generation. Lastly the path analysis helps to understand places and the memory of the typical rural traditions. In fact, as Cristian Norberg-Schulz wrote [ 996 ] 
Fig. 5. Evolution of the connecting tissue: on connecting tissue on an connecting tissue on an 818 cartographic basis Reale Officio Topografico di Napoli); on the rig
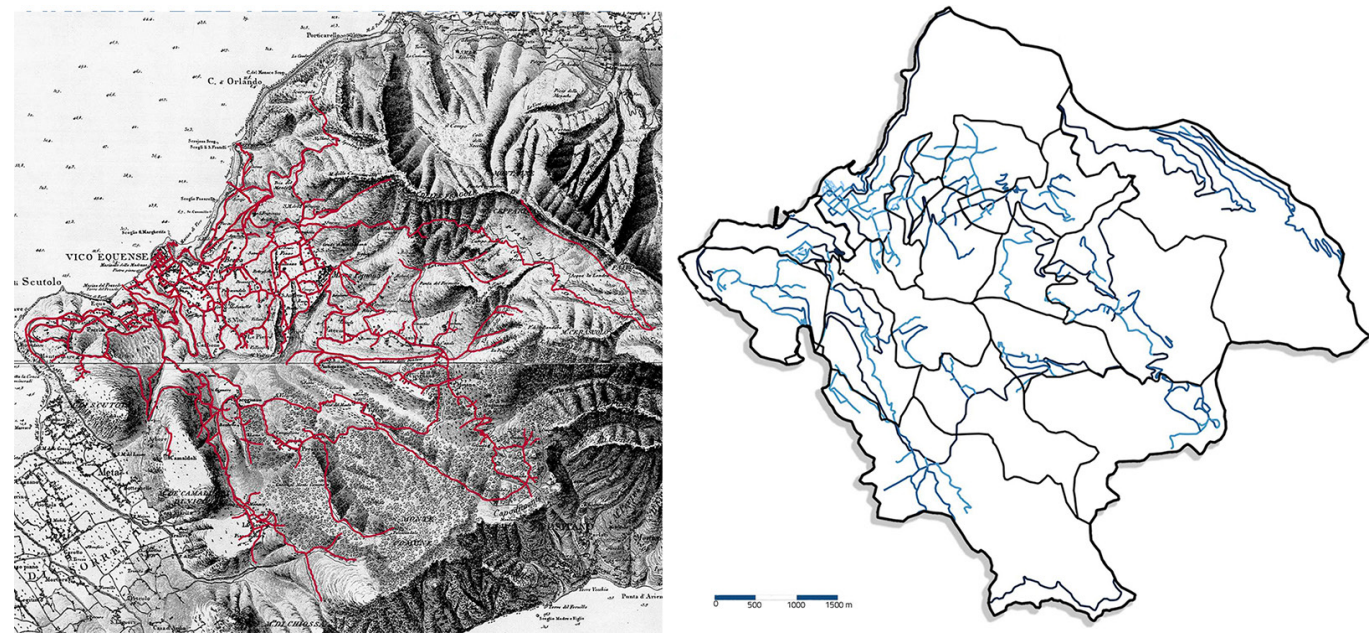

"every place has its own identity and the man's duty is to understand and take care of it through a never-ending process. All ages reveal some place quality and cover others".

It was primarily requested to prepare the individual path form, that includes a set of information to understand its morphological characteristics, weakness and also possibilities of fruition. This form is divided in three parts with a gradual definition of information, for example general information of topography, geometry and altitude, explanatory photos, planimetry, biographical notes, data on flooring type and maintenance. The reference code and the information, that are contained in each form, enable the establishment of a geo-referenced database with the inclusion of its path information system (SIP). The geodatabase is structured in a streamlined way, that manages and updates the information. It also includes information in different formats (fig. 6), that are useful to complex queries and development of thematic maps [Gaiani 20।2].

For this research the case study pathway is Meta-Fornacelle, that is about 750 metres and links the neighbouring country Meta di Sorrento to Fornacelle, district ofVico Equense (fig. 7).
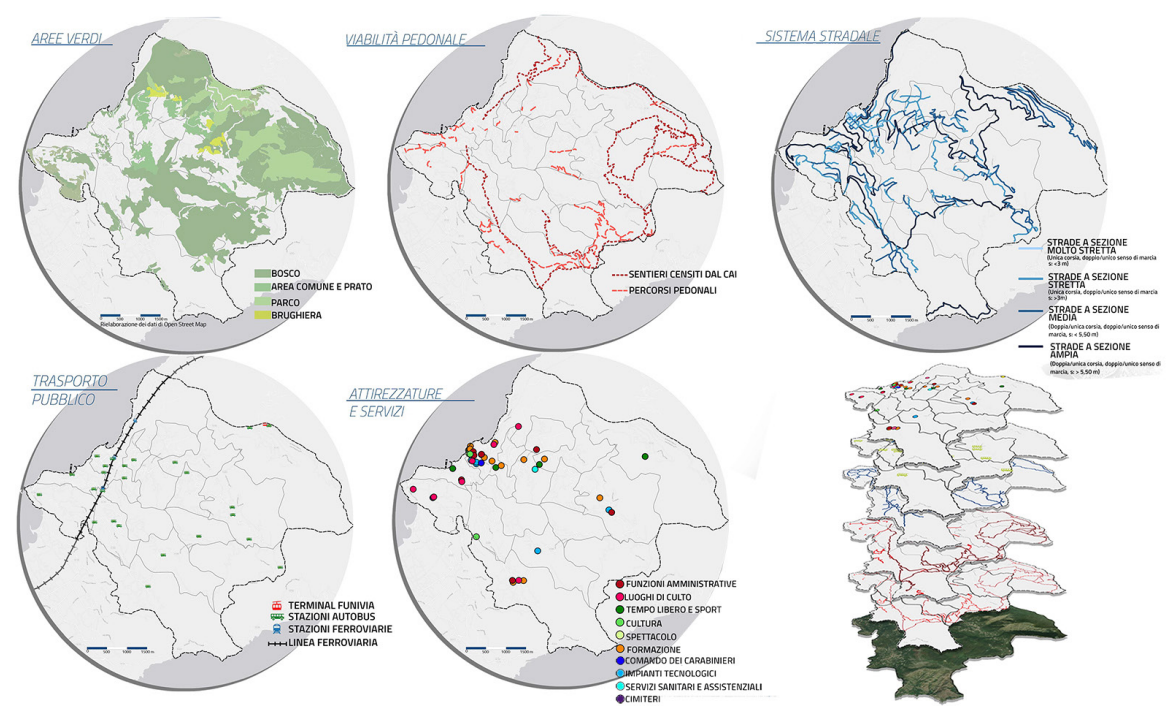

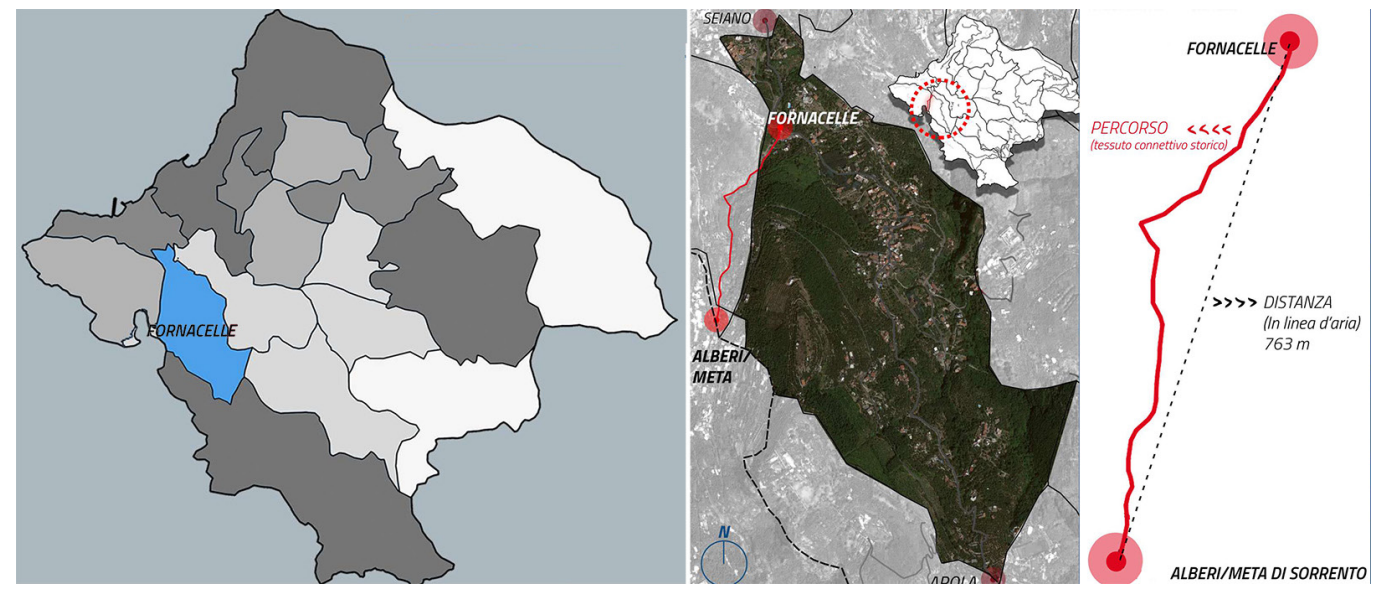

\section{An app proposal for knowledge and fruition}

The information transfer has become of primary importance for institutions and to satisfy the wide and diversified user exigencies. The creation of a software application, open source and user friendly for mobile devices, is one of the strategies for the enhancement aim. The ConnectingVICO app has been designed for pathway and for the cultural hub creation whose description is not present here- that could be realized renovating not currently used public buildings. As it can be seen in figure 8, the app enables you to choose the place of interest, that is identifiable through the smartphone GPS. Then you can get in the pathway or in the cultural hub. So that virtual communication presents itself as corporeity valorisation and it extends the boundaries [lppoliti 2018].

There are informations about the path characteristics (length, type of path, different in altitude, slopes, points of interest, estimated journey time depending on visitors, historical information, etc.); it is possible to map your own path with the estimated journey time, meters travelled, own points of interest, photograph or video taken during the trip. It is also possible to interact with QR-code, which are on the information totem on the path (fig. 9). As previously said, it is possible to use the services offered by the cultural hub. Experience

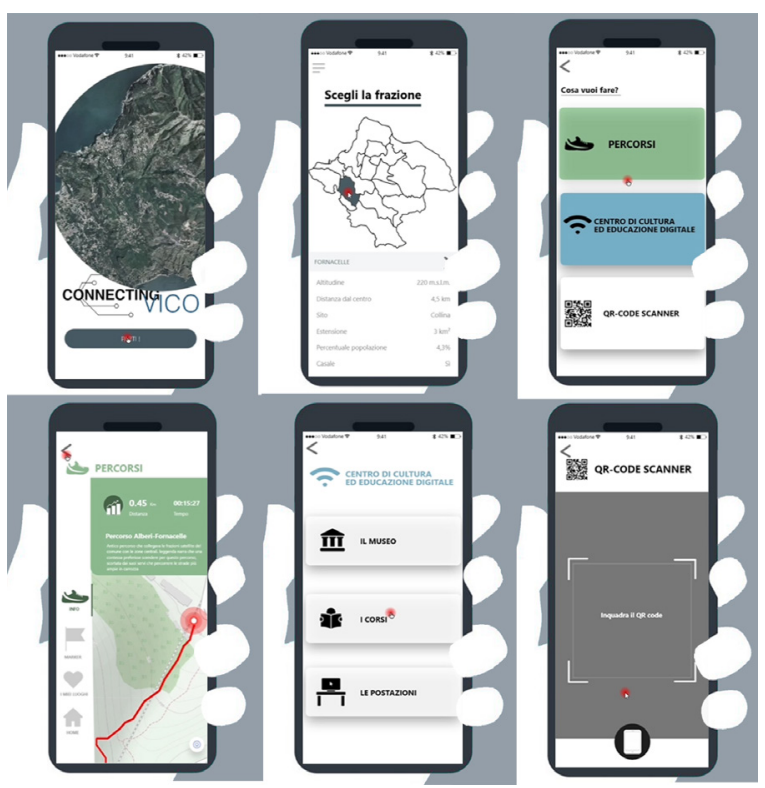


Fig. 9. Some of the app graphical output. Plano-altimetric map and critical or interest points the territorial section is resented at different height/length scales).

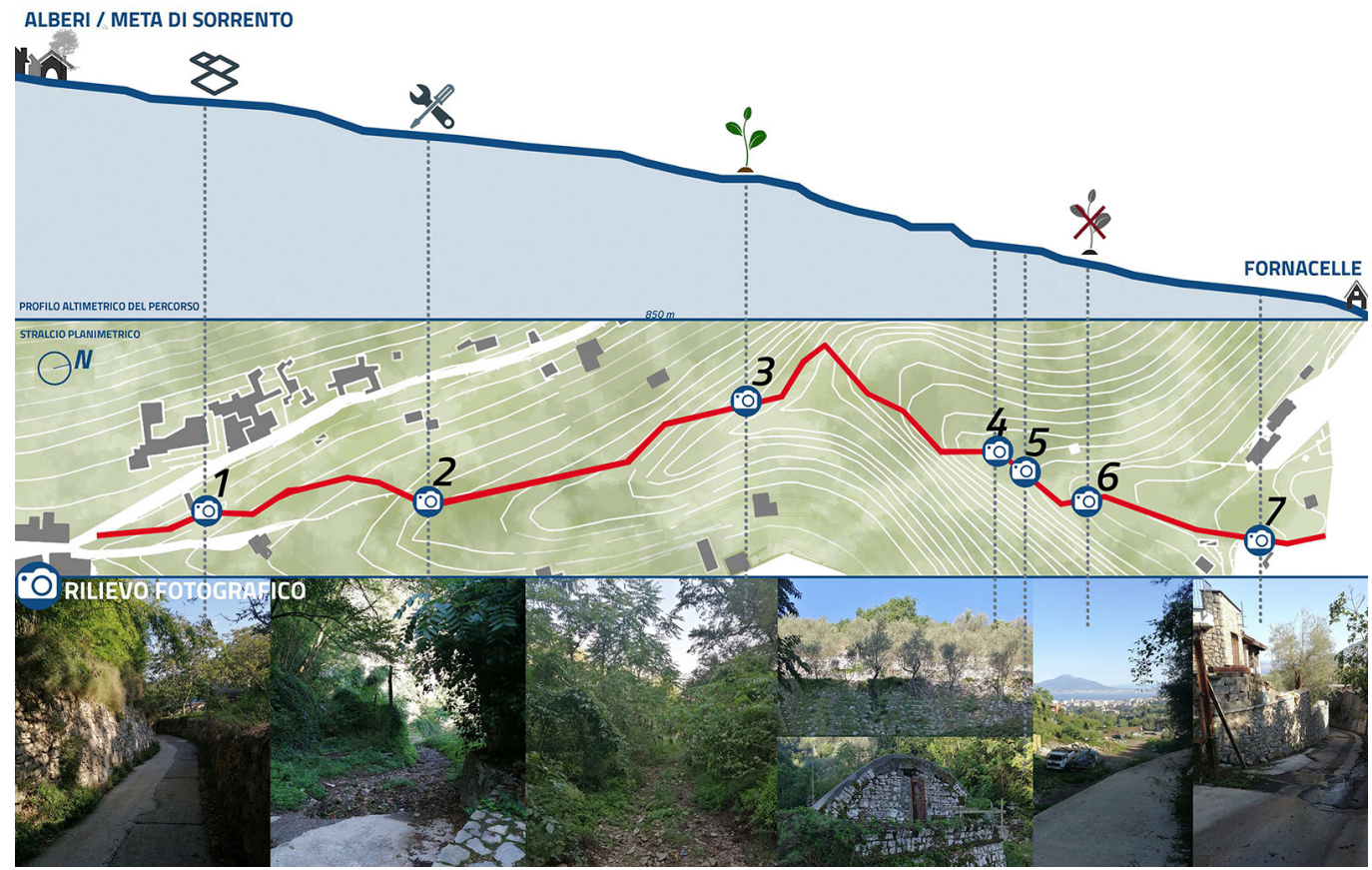

of immersive reality are planned for each territory. So that virtual communication presents itself as corporeity valorisation and it extends the boundaries [Ippoliti 20 I 8]. Therefore, the virtual model of the path has been developed through modelling procedures image-based on photogrammetric survey with drone (fig. 10). In particular, images summarize the survey activity of a stretch of Fornacelle-Meta path, that is the most significant natural stretch, ranging from point 4 and 6 in the planimetric excerpt. Trees and shrubs could have affected the flight operations due to their interference with the drone. They could have also established an excessive cleaning up pictures.

The model was used for the immersive reality applications (figs. I I, I2) through specific software and hardware. The idea is to allow the remotely "virtual travel" in order to enable people, who are away or unable, to enjoy the beauty of the place.
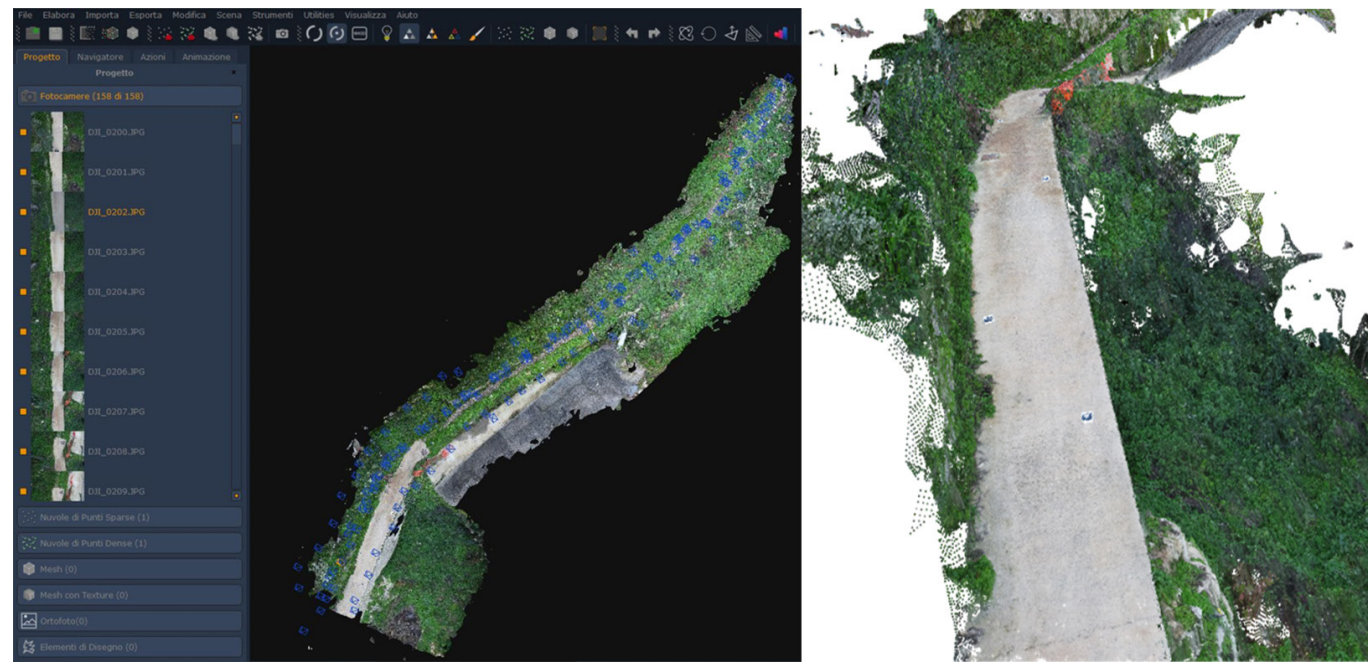


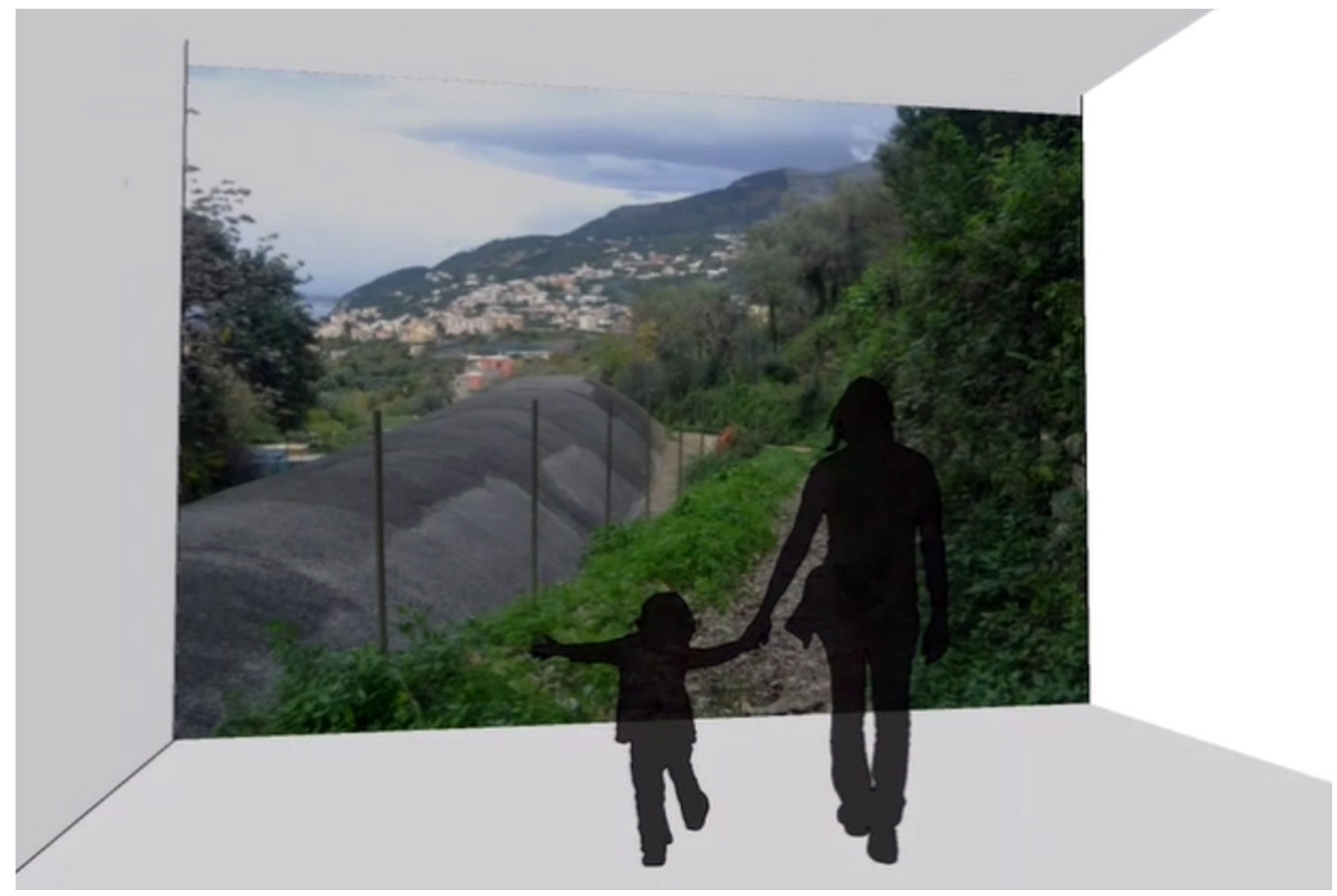

\section{Conclusions}

The presented work addresses some important aspects for the Drawing sector, related to a vast theme such as that of the identification of processes and visual artefacts for the enhancement of some areas in identity crisis with high potential. Vico Equense represents one of the many and complex scenarios of our country rich in history, culture, landscape beauties, architectural, archaeological and urbanistic emergencies in which the activities of Drawing -in synergy with other sectors- can contribute to enhancing aspects (material and intangible) even apparently heterogeneous. The adopted methodology defines multi-graduated process of sustainable and participative regeneration in the digital domain. This results in the conscious acquisition of data and in their elaboration in an effort of appropriate buildings individualisation. These structures could become places for sharing, for territorial promotion and for conscientious digital education. Obviously, this process needs also to test new communication modes and hybridized languages, that are useful in the strong relationship re-establishment of local community's past tradition.
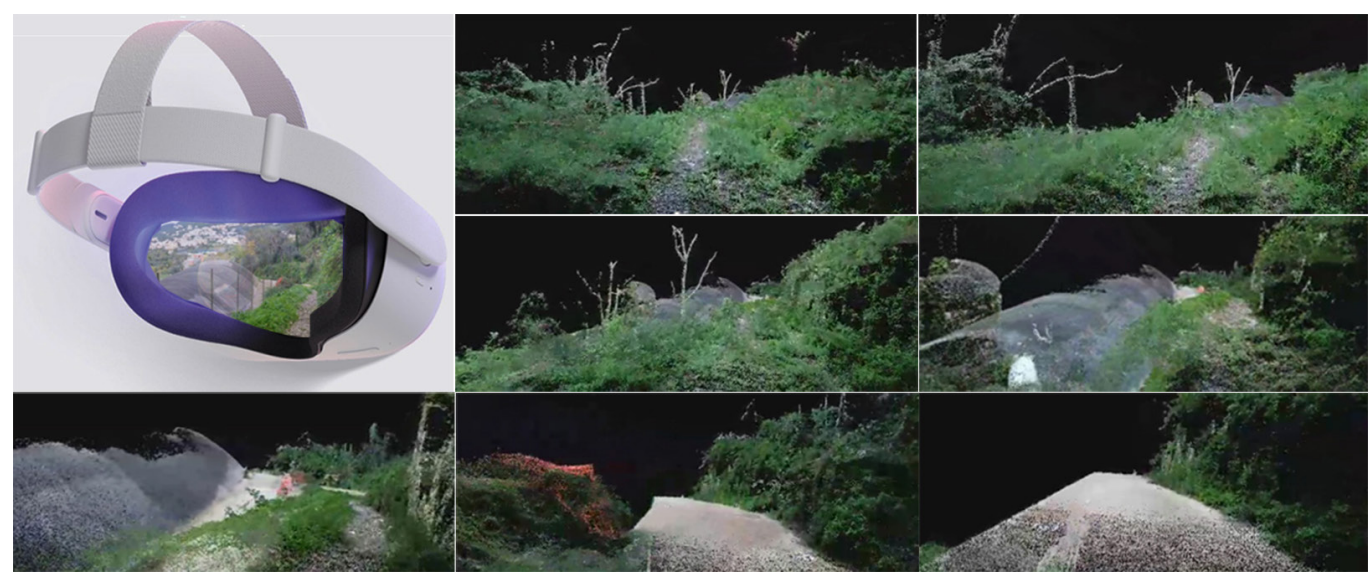


\section{Notes}

[I] According to the Digital Economy and Society Index 2020 (DESI) Italy is at 24th place between 28 member states.

[2] The complete study is realized under REMlab (Survey and Modelling Laboratory) of Department of Civil, Building and Enviromental Engineering of the University of Naples Federico II, which involves also undergraduate internships.

[3] Until XIX century the villages, denominated in the modern age districts, were I3: Bonea, Massaquano, Moiano, Ticciano, Prezzano, Arola, Fornacelle, Pacognano, Seiano, Montechiaro, San Salvatore, Sant'Andrea, Vico.

[4] Monte Sant'Angelo was rich in neviere, deep holes, in which snow was maintained during the winter period. The neviere were filled with layers of snow and beech leaves, that protect the snow until it was carved in regular blocks. They were beneficial to relieve the heat of summer.

[5] The construction of the new sorrentine street began the realization of a new road, which head down to the beach. It was built by engineer Agresti in 1849-1850.

\section{References}

Caniglia Rispoli C. (2003). Come rappresentare i percorsi urbani. In L. M. Papa (a cura di). Disegno e disegni dei percorsi urbani. Napoli: Cuen.

Castells M. (1998). The Information Age: Economy, Society and Culture. In Environment and Planning B: Planning and Design, 25(4), pp 63 I-636. Milano: Egea.

D'Auria S., Diana L. (2020). The regeneration of public heritage estate in Campania: an assessment approach. In Sustainable Mediterranean Construction. Land culture, research and technology, I I, pp. 35-40.

Dondona C. A., Piemonte I. (2019). Turismo montano e valorizzazione del patrimonio escursionistico regionale. II Tour del Monviso. In EyerReg, vol. 9, n. 4, pp. $172-178$.

European Commission (2020). Indice di digitalizzazione dell'economia e della società (DESI).

Fino L. (200 I). Da Castellammare a Massa. Vedute e costumi della costiera sorrentina. Disegni, acquerelli e stampe dal XVI al XIX secolo. Napoli: Grimaldi \& C.

Gaiani M. (2012). Creare Sistemi Informativi per studiare, conservare, gestire e comunicare sistemi architettonici e archeologici complessi. In DisegnareCon, vol. 5, n. 10, pp. 9-20.

Ippoliti E., Casale A. (20 I8). Rappresentare, comunicare, narrare. Spazi e musei virtuali tra riflessioni e ricerche. In A. Luigini, C. Jalongo G. (1994). Città e casali della penisola sorrentina. Roma: Officina Edizioni.

Norberg-Schulz C. (1996). Architettura: presenza, linguaggio e luogo. Milano: Skira.

Ortiz P., Matas M. (2009). Experiences about fusioning 3D digitalization techniques for cultural heritage documentation in Cáceres wall (Spain). In 3D-ARCH '2009, ISPRS, vol. XXXVIII-5/WI.

Pacichelli G. B. ( 1703). Il Regno di Napoli in prospettiva diviso in dodeci provincie. Napoli: nella stamperia di Michele Luigi Mutio.

Pancioli (a cura di). Ambienti digitali per l'educazione all'arte e al patrimonio, pp. I 28, I 5 I. Milano: FrancoAngeli.

Papa L. M., D'Auria S. (2020). Rilievo e modellazione digitale: un percorso critico per la valorizzazione del Castello di Ischia. In J. Navarro Palazón, L. J. García-Pulido (a cura di). Defensive Architecture of the Mediterranean, International Conference on Fortifications of the Mediterranean Coast, vol. X, pp. 407-4I 4. Granada: Universidad de Granada.

Zola L. E. (2019). Percorsi di valorizzazione dei sentieri alpini e trekking someggiato. In AA.V. (a cura di). Beni e risorse culturali delle comunità alpine. Fra storia e valorizzazione, pp. I45-155. Cherasco: CISIM.

\section{Authors}

Saverio D’Auria, Università degli Studi di Napoli Federico II, saverio.dauria@unina.it, Lia Maria Papa, Università degli Studi di Napoli Federico II, Impapa@unina.it

To cite this chapter. D'Auria Saverio, Papa Lia Maria (202I). Connessioni (im)materiali per una rigenerazione sostenibile/(IM)Material connections for a sustainable regeneration. In Arena A., Arena M., Mediati D., Raffa P. (a cura di). Connettere. Un disegno per annodare e tessere. Linguaggi Distanze Tecnologie. Atti del $42^{\circ}$ Convegno Internazionale dei Docenti delle Discipline della Rappresentazione/Connecting. Drawing for weaving relationship. Languages Distances Technologies. Proceedings of the $42^{\text {th }}$ International Conference of Representation Disciplines Teachers. Milano: FrancoAngeli, PP. 1545-1592. 